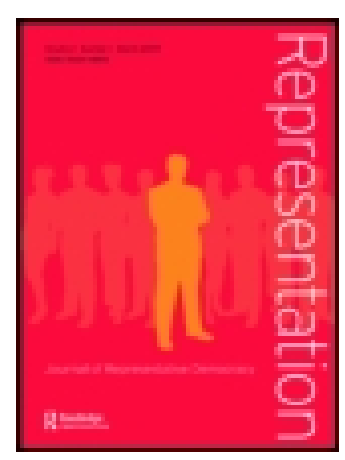

\title{
Representation
}

Journal of Representative Democracy

\section{Democratic representation and democratic sanctions}

\section{Corrado Fumagalli}

To cite this article: Corrado Fumagalli (2018): Democratic representation and democratic sanctions, Representation, DOI: 10.1080/00344893.2018.1502207

To link to this article: https://doi.org/10.1080/00344893.2018.1502207

$$
\text { 曲 Published online: } 26 \text { Jul } 2018 .
$$

Submit your article to this journal $₫$

View Crossmark data ־ 


\title{
DEMOCRATIC REPRESENTATION AND DEMOCRATIC SANCTIONS
}

\author{
Corrado Fumagalli
}

\begin{abstract}
In this paper, I argue that citizens have an entitlement to sanction representatives, but representatives have tools to anticipate this sanction and reconstruct their views in order to anticipate the views of the people they are supposed to represent. I also argue that represented and representatives have an entitlement to sanction democratic representative institutions and practices, but, unless citizens across the spectrum of all representative relationships agree on many fronts, sanctions are likely to violate the democratic requirement that all subjected to a collective decision should not be mere objects of coercion.
\end{abstract}

\section{Introduction}

There is a widespread belief that strengthening representative institutions may cure the deficit of democratic institutions and practices. Instruments of direct democracy, such as referenda and public consultations, are increasingly popular around the world, and experiments with a deliberative intent have been mushrooming in a number of different cities, districts, and states. However, within the framework of representation theory, scholars have paid little attention to the justificatory component of these reforms and to the (more or less) democratic character of the process that, from a certain democratic representative institution, brings about a new (more or less) democratic representative institution. This paper contributes to these discussions by addressing the two issues in continuity with one another.

Does democratic representation incorporate an entitlement to change democratic representative institutions and practices? Yes, it does. So, I argue that in representative democracies, an entitlement to sanction representatives and an entitlement to sanction representative democratic institutions and practices are normative premises for assessing, controlling, and changing democratic representative institutions. But this is just a part of the story. As I shall demonstrate in this paper, it is very difficult to change democratic representative institutions and practices through systems of actions that, over time, are fully coherent with the democratic character of democratic representative institutions. This is not great news. After all, changing fundamental rules often requires super-majorities because of reasonable disagreement. Here, I argue that, given the many simultaneous objects of disagreements that the decision of innovating democratic representative institutions entails, and accepted the democratic principle that members of the demos are not merely objects of coercion, a trade-off between truly democratic ambitions and reforms that are achieved through partially democratic processes is indeed the best we can realistically hope for.

Therefore, the paper unfolds as follows. In the following section, I shall offer a minimal definition of democratic representation. From this definition, in the second section, I shall argue that democratic representation justifies incremental reforms and drastic changes in democratic representative institutions. The third section of the paper examines the democratic 
character of democratic innovation in the context of democratic representative institutions. In the last two sections, then, I shall explain why it is so difficult to pass from a democratic representative institution to another through processes that are fully democratic.

\section{Democratic Representation}

This paper is about democratic representation (Plotke 1997: 31; see also Disch [2011]; Dovi [2002]; Manin [1997]; Mansbridge [1999, 2003]; Urbinati [2006]; Urbinati and Warren [2008]; Castiglione and Warren [2013]) in plural societies, not representation in general (Rehfeld 2006, 2018). If we think most contemporary normative and empirical disputes about representation occur within a more or less explicit democratic framework, this declaration of intents may seem redundant, if not problematic. Some readers would collapse the meaning of the two terms into one concept: representation, they would say, is always democratic. I think this is a fuzzy reading that is short on analytical accuracy. It makes it difficult to recognise and evaluate the democratic (and the nondemocratic) character of democratic (and nondemocratic) representation. By taking representation in general and democratic representation as one and the same thing, we may lack the required conceptual precision to justify the reasons why we believe representation in institutions such as Chinese local congresses is not democratic representation but still a kind of political representation that deserves attention (e. g., Manion 2015). In this section, I shall provide a definition of democratic representation that is deliberately minimal and descriptive. It shall be sufficiently abstract to be compatible with the different ways other scholars conceptualise representation in a democratic sense.

The scholarly literature argues that democratic representation is a process (e.g., Disch 2011: 108-9; Pitkin 1967: 218; Plotke 1997: 32; Young 2000: 132). This process may entail a dialogic phase in which citizens clarify their preferences (Plotke 1997: 32) or interests (Young 2000: 132; see also Squire [2008]: 190). Notably, this process is not static: 'representing' is an activity that unravels diachronically (e.g., Mansbridge 2003: 518; Rehfeld 2011: 633) through presentations and re-presentations, creations and re-creations of claims, and, perhaps, collective identities. Certainly, it entails a phase through which a certain being comes to be a 'democratic representative' (e.g., Rehfeld 2006; Saward 2010). On this view, different systematic series of actions (including voting, but also deliberation, lottery, or other generally accepted procedures [e.g., Manin 1997; Syntomer 2010]) add the temporary ontological attribute of being a member of the demos that all other members of the demos (including other members with the same ontological status [Rehfeld 2006]) could recognise as a democratic representative. In this way, the process constitutes a distinctive relational typology: a political relationship between two poles, the represented $(\mathrm{Y})$ and the representative $(\mathrm{X})$, in the activity of democratic decisionmaking. So this process brings about a kind of political relation between a certain $X$ and a certain $Y$. In the different forms of representation as social and political facts, democratic representatives may be formal political actors, such as presidents, senators, or other elected officials. But they may also be informal political actors, such as lobbyists or leaders of civil-society organisations, international nongovernmental organisations, or social movements (Montanaro 2012). The represented may be living and nonliving human beings.

I have said that, generally speaking, both $X$ and $Y$ are members of the demos. Qua members of the demos, they enter into a special relation with one another because a systematic series of actions constitutes them as a representative and as a represented for a certain period of time. The representative $X$ might be in relation with several other members of the demos. Meanwhile, $\mathrm{Y}$ might enter into a special relation with different representatives at the 
same time. In principle, this process adds a layer of mediation $(X)$ between the government and Y (Rehfeld 2009: 214-16). However, this layer of mediation is contingent on Y's autonomy as a moral being who has reasons to choose $X . Y$ can have many different reasons, but this does not challenge the presupposition that, within the interpersonal relationship between a represented and a representative, the location of authority remains in $Y$ as an autonomous being who has to be the author of his or her own laws and can change his or her mind (e.g., Manin 1997; Mansbridge 2009).

The relationship between $X$ and $Y$ may be understood as unidirectional (from $X$ to $Y$ ) or as bidirectional (from $X$ to $Y$ and from $Y$ to $X$ ). For instance, the traditional model of democratic representation is unidirectional. Hannah Pitkin captures this when she writes that in democratic representation, the 'representative must be responsive to [the represented] rather than the other way around' (1967: 40). Lisa Disch argues that representation is dynamic and interactive: 'Representatives', she writes, 'look backward to preferences that have been expressed, and orient themselves forward in a speculative mode toward what their constituency might want or be included to want at the next election' (Disch 2011: 100; see also Urbinati [2000]).

Moreover, the relation between $\mathrm{X}$ and $\mathrm{Y}$ has two components: a causal component and $\mathrm{a}$ modal component. The causal component explains why a certain process has brought a specific $X$ to represent $Y$. The modal component expresses a continuous indicator that helps to evaluate the relation between $X$ and $Y$, given the specific causal component that links representatives and represented. For instance, Eline Severs says that 'responsiveness' is a systemic indicator of the quality of representation (2010). Lisa Disch submits 'reflexivity' as the normative standard for evaluating political representation (2011). When the continuous indicator approximates its minimum value, the process may produce a new causal component that makes the same $\mathrm{X}$ or another $\mathrm{X}$ a representative of $\mathrm{Y}$.

When we speak of democratic representation, it is plausible to say that the process and the relationship between $X$ and $Y$ are ascribable to a system of institutions and practices in which generic norms of democracy are realised. Typically, democratic theory holds (at least) that the democratic module requires political arrangements to instantiate the principle that all affected by collective decisions should have an opportunity to influence the outcome (Urbinati and Warren 2008). Let me unpack the meaning of this module. First, most democratic theorists presuppose that each democratic regime (national or international) has a demos (e.g., Christiano 2008; Habermas 1996; Näsström 2007). Second, they assume democracies are regimes in which the many rule. Third, they tell us how to identify these many: they are all those affected by a collective decision. Often, as Sofia Näsström (2011) has argued convincingly, this way of reasoning collapses two principles (the all-affected principle and the allsubjected principle) into one.

The all-subjected principle assumes a certain political unit (national or international) and focuses on individuals. From this, it takes existing boundaries as thresholds for inclusion and exclusion (Benhabib 2004: 215; Gould 2006: 49; Näsström 2011: 116-20). The all-affected principle challenges the idea of pre-existing borders, and it focuses on the interests people have or may have. On this view, the scope of democratic decisions draws the boundaries of a democratic constituency. Some decisions may touch the interests of people living within a state's borders; other democratic decisions, such as border regulation or climate-change policies, may touch the interests of individuals beyond the state (Näsström 2011: 126). Seen in this way, the scope of the demos may expand outside the borders of a state (Pensky 2007), intergenerationally (Skirbekk 1997), and even to animals and plants. 
Most democratic theorists (e.g., Urbinati and Warren 2008; Young 2000) acknowledge the complexity of democratic decision-making in an increasingly interconnected world and the urgency of including extraterritorial and nonterritorial actors. Nevertheless, in existing representative democracies, residency (if not citizenship) remains the most obvious channel to democratic participation. In modern constitutional democracy, individuals can claim participation qua residents (or citizens). In international or supranational institutions, individuals can participate qua residents of member states. It seems, therefore, plausible to think that what Urbinati and Warren call the all-affected principle is, in fact, the all-subjected principle. ${ }^{1}$

In the context of representation theory, the democratic module specifies what $X$ and $Y$ can do. Representation is democratic when it is at least coherent with the all-subjected principle. There is no single procedure to realise this principle, but each process should be transformative so that some members of the demos become members of the demos who are recognised as democratic representatives. In its minimal form, such as the 'one person, one vote' formula, this principle entails both choosing the best representative and a competitive struggle for the people's vote within the predetermined boundaries of the relevant political community. Otherwise, it may denote a political and deliberative involvement in the democratic process of decision-making, as well as a multiplication of the sites of debates (Näsström 2015: 10; Urbinati 2006: 196).

From this, it follows that the relation between $X$ and $Y$ is democratic even if $X$ and $Y$ do not foster the norms and values distinctive of democracy. Not all representatives do in fact engage in advocacy of democratic values, despite moving with a system of institutions and practices through which generic norms of democracy are realised (Dovi 2007: 15-18). Similarly, the relation between $X$ and $Y$ is democratic even if $X$ and $Y$ do not respect democratic norms. For instance, when a representative $X$ refuses to deliberate with other citizens on the grounds that he is obeying God's direct command to him, it seems odd to think that the relation between $Y$ and $X$ is not democratic (Dovi 2007: 15-18). It also seems odd to think the democratic character of an interpersonal relationship of representation between $X$ and $Y$ can be judged according to the effects of what $X$ does as a participant in the democratic system (Kuyper 2016). I hold that an interpersonal relationship between $X$ and $Y$ is democratic in a more fundamental way. It embodies the principle that in democracy, the many rule and, therefore, individuals are not merely objects of legislation. Directly or through their representatives, autonomous agents take part in the formation of coercive rules (Gutmann and Thompson 2004). History has been telling us that interpersonal relationships that are democratic in character may bring about antidemocratic outcomes. However undesirable as they might be, these outcomes do not make the interpersonal relationship of representation antidemocratic. Antidemocratic outputs may make the whole system less democratic, but this seems to be another kind of question.

In this section, I have gestured towards a minimal and descriptive definition of democratic representation. Specifically, I have held that democratic representation expresses a process ascribable to a system of institutions and practices in which the all-subjected principle is realised. This process brings about a temporary and political relation between a certain $X$ (the representative) and a certain $Y$ (the represented) that is contingent on a causal and a modal component. In the next sections, I shall focus on representative relationships when represented citizens feel they are misrepresented and when both representatives and citizens feel they are misrepresented. 


\section{Representative Relationships and Three Entitlements}

I have argued that all democratic representative relationships are distinctive relational typologies that, in the political sphere, arise from a process that brings together $\mathrm{X}$ and $\mathrm{Y}$. So democratic representation constitutes two kinds of political person: the representative and the represented. $X$ and $Y$ remain two distinct poles. In this way, the represented can judge and control those who represent them, with two provisos. First, representatives should act on behalf of the causal component that informs the representative relationship (Hamilton 2014: 113-14; Plotke 1997: 30-31). Second, such a component may change in the future if represented citizens feel they are somehow misrepresented. So the process of democratic representation brings about a relationship between $X$ and $Y$ where both $X$ and $Y$ are active. And representative relationships are venues of participation and direct influence as well as the sites of political struggles (Disch 2011; Hamilton 2014; Näsström 2015; Plotke 1997; Urbinati 2000, 2006; Young 2000). Representatives have a significant degree of autonomy, but the represented can inform and control what they do. To put the same idea in other terms, representative relationships combine 'an entitlement to represent something/someone' and 'an entitlement to sanction representatives'. By 'sanction', I mean a mechanism of control for enforcing a represented citizen's standards in the representative relationship.

By being recognised as 'a representative' within the perimeter of a democratic political sphere, it is permissible for a citizen to do certain things, bear the resulting burdens, and enjoy the resulting benefits. Simultaneously, by being recognised as 'represented' within the perimeter of a democratic political sphere, citizens can assess and control their representatives (Castiglione and Warren 2013: 155: Runciman 2007: 97). Taking these points together, through the process of democratic representation, representatives acquire a distinctive capacity to represent the represented, provided the represented are convinced by the representatives' answer to the causal component. At the same time, through the process of democratic representation, the represented acquire a distinctive political capacity to sanction other citizens-their representatives-because of their feelings concerning the modal component.

Representatives whose actions provoke explicit objections by those they claim to represent, even if they believe they are acting in agreement with the causal component both parties agree with, are objects of the judgment of the represented, whose evaluative criteria they cannot entirely predict. Lawrence Hamilton submits that representation should be constituted so that citizens have real control over representatives, in the sense of having the institutional means to remove them from office if their judgments are deemed poor in a number of ways $(2014,2017)$. In the same vein, Suzanne Dovi says that 'opportunities for citizens to evaluate and sanction their representatives lie at the heart of the practices of representative democracies' (2007: 96).

Here, two remarks are in order. The mere observation that democratic representation includes the normative justification of two sanctions does not make the represented well equipped to unveil all kinds of misrepresentation. In some cases, representatives are misrepresenting the interests of the represented but the represented are not capable of acknowledging this. Here the represented are not actually using their sanctions, but sanctions are indirectly informing what the representatives are doing (e.g., Manin 1997). Moreover, the interpersonal relationship of democratic representation associates $X$ and $Y$ in a distinctive manner. And this link includes the entitlement to sanction (among other things). For this reason, despite the emphasis on sanctions, I think the present account is also consistent with the selection model (Mansbridge 2009). The selection model focuses mostly on what occurs ex ante, such 
as putting the appropriate representative in office according to policy congruence or alignment of objectives (Giger and Lefkofridi 2016; Lefevere et al. 2017), rather than what occurs during the principal-agent relationship. My account is descriptive, and it says that in democratic representation, there are two kinds of sanction. I am not saying they are more relevant than congruence and alignment. Actually, Mansbridge also accepts that the represented retain the capacity to replace selected representatives (2009).

Moreover, even if the actual opportunity and capacity to hold elected officials to account for their actions and policies is limited, electoral mechanisms are frequently seen as effective means for rejecting past representatives at the ballots (Mansbridge 2003: 516, 2011: 624). Therefore, citizens may issue binding instructions to the representatives, or they may change the procedures by which representatives are appointed (Runciman 2007: 97). In the case of non-elective representatives, varied forms of control, such as governance networks and deliberative devices, and identification in terms of nonparty identities may ensure better control of representatives (Saward 2009: 8). Meanwhile, representatives are aware of the entitlement to sanction. Representatives may use their political power deceptively and against the political will of the represented: rhetorical arguments, symbolic rewards to buy off citizens who had been making more substantial demands, propaganda, the appeal to common sense, usage of terms out of context, withholding relevant data and information, and overloading citizens with too much information are all instances of manipulatory politics that may inhibit the exercise of the entitlement to sanction (Goodin 1980). Further, representatives may bolster their position by constructing favourable representations of themselves (Saward 2009: 7). ${ }^{2}$

Misrepresentation also may be the result of distortions that lie beyond the representative relationships. Certainly, it may result from the failures of representatives, but it may also result from the architecture of some representative democratic institutional arrangements (Dovi 2007: 49). ${ }^{3}$ For example, the congressional practice of declaring bills 'emergencies' does not allow for representatives to have time to read and consult their constituents about how legislation would adversely affect them (Dovi 2007: 49). In the EU, decision-making procedures at the supranational level have been blamed for concentrating much of the decisionmaking power in the executive. In the same vein, transformation in the shape of the political party may alter the representative relationship so that it goes beyond the interpersonal relationship between $\mathrm{X}$ and $\mathrm{Y}$.

However, at the heart of democratic representation, there is also an entitlement to assess and control a system of institutions and practices in which generic norms of democracy are not realised. In principle, both representatives and represented have this entitlement to resist as a form of voice to be exercised under extreme circumstances, cases where the law systematically differs from the will of the community at large (Gargarella 2003). In these cases, representative democratic institutions may produce outcomes that are somehow consistent with fundamental democratic values, such as freedom and equality. Nevertheless, these outcomes are problematic as they violate the principle that, directly or through representatives, autonomous agents take part in the formation of coercive rules. In this situation, qua autonomous members of the demos who have the right to take part in the formation of collectively binding decisions, both represented and representatives have the right to sanction representative institutions and practices. This entitlement is even prior to the entitlement to sanction representatives. It concerns the relationship between autonomous individuals and potentially coercive political institutions, democratic and nondemocratic. 
However, it does not excuse every behaviour. Being grounded in the right to resist, the entitlement to sanction representative institutions requires a degree of proportionality (Kaufmann 1985-86). Otherwise, the right is not merely that of resistance but of revolution. In particular, the right to resist, as opposed to a right of revolution (Wolin 1982), has as its goal a return to the original condition-the ideal without distortions-or to improve the original condition in line with its own grounding principles (Ginsburg et al. 2013; Kaufman 1985-86).

This opens the discourse on proportionality and resistance when members of the demos have a sufficient justification to sanction representative institutions. As Archon Fung has already argued, the response to this question implies a complex internal calculus (2005). It weighs the ethical costs of taking action that violates norms against uncertain gains for justice and democracy (2005: 402). When existing practices and institutions are 'flawed but improvable' (Fung 2005: 403), the ethical costs of taking action have to be as low as possible, and the democratic gains have to be transparent. When existing practices and institutions fail to respect the all-subjected principle, democratic gains have to be transparent, but, in this case, the ethical costs of taking action can be higher. Still, the choices of means should be scaled against two things, the rejection of the all-subjected principle and the idea that individuals are not merely objects of coercion.

These ideas are not new. In the literature on democratic representation, it is often assumed. For instance, Dovi writes that representative relationships work on the assumption that representative democracies need to provide fair procedures for giving voice to concerns of citizens and for authorising binding decisions (Dovi 2007: 14). Actually, the question of legitimate popular uprisings has plagued political theories for a very long time. For the American founders, this question was of such deep importance that it stands at the very basis of modern constitutionalism as we know it. 'Whenever any Form of Government becomes destructive of these ends', the American founders wrote,

it is the Right of the People to alter or to abolish it, and to institute new Government, laying its foundation on such principles and organizing its powers in such form, as to them shall seem most likely to effect their Safety and Happiness. (Declaration of Independence, para. 2)

In the context of democratic representation, the entitlement to sanction representative democratic institutions and practices may lead to justifying the demand for incremental reforms when other remedies to ensure representation fails. For instance, we can think of a parliamentary reform, new party lists, the composition of new constituencies, the construction of schemes for proportional representation, caucuses, district assemblies, mini-publics, citizen panels, participatory budgeting, updated tribunals of the plebs, constitutional revisions, and institutional means that increase government's attentiveness towards the electorate and the representatives. Moreover, the entitlement to sanction representative democratic institutions and practices may lead to justifying the demand for drastic changes when incremental reforms fail. These actions are intended to remind governments that citizens are the ultimate source of legitimate rule. For this reason, a provision is inherent in the entitlement to sanction the system of institutions through which democratic values are realised: change has to occur in a democratic way, and it has to lead to democratic institutional forms. In other words, the entitlement to sanction the system of democratic institutions is solely about the opportunity to create more democratic representative institutions.

So representative relationships comprise three entitlements: $X$ 's entitlement to represent $Y, Y$ 's entitlement to sanction $X$, and $X$ and $Y$ 's entitlement to sanction a system of institutions and practices in which generic norms of democracy are realised. The last entitlement originates 
in a general entitlement to resist both democratic and undemocratic institutions and practices, under special circumstances.

Yet it is not necessarily true that, in the present of democratic representative institutions, the instruments and mechanisms of democratic sanctioning will make institutions more responsive. ${ }^{4}$ Among other things, the responsiveness of democratic representative institutions is contingent on the competence of the represented people and on the competence of the demos as a whole in a context in which the represented can be manipulated but also the representatives are vulnerable to implicit bias and exogenous control. ${ }^{5}$ However, as I shall argue in the following, it is true that, in order to count as democratic innovations, incremental reforms and drastic changes have to improve at least one of the possible democratic axes. When existing democratic representative institutions do not respect fully the all-subjected principle, incremental reforms and drastic changes may reconstitute the demos, but this is not necessarily the case. It may also happen that, from the normative standpoint of the all-subjected principle, there is no significant improvement. Yet, there are gains in other relevant normative areas, such as, among many others, accountability, trust and transparency. It is evident that these hard balances would require a longer discussion. In this paper, given the focus on the justificatory component of reforms and on the process leading to the implementation of democratic change, I shall maintain that incremental changes and drastic reforms aim to respect fully the all-subjected principle. For this reason, in the next section, I shall explain the link between democratic innovation and the all-subjected principle. In this way, I shall be able to identify a starting point (that of existing democratic representative institutions), an endpoint (that of new democratic representative institutions) and a transition between these two points. Such a transition will be the object of the last sections of the paper.

\section{The Democratic Character of Incremental Reforms and Drastic Changes}

I have said that the democratic module of democratic representation requires democratic representative institutions to instantiate the principle that, thanks to the work of their representatives, all members of the demos who are subject to a collective decision should have an opportunity to influence the outcome. I have also argued that, even within the framework of a theory of democratic representation, when existing practices and institutions do not fully respect the all-subjected principle, sanctions to democratic representative institutions, such as incremental reforms and drastic changes, are justified.

If we think that incremental changes and drastic reforms aim to improve the democratic status quo of otherwise stable democratic representative institutions, the question of who have the right to participate in the decisions of a reformed democratic representative institutions is not trivial. At a minimum, it helps to compare present and future states of affairs. Nevertheless, in the literature on democratic innovations, references to the all-subjected principle are not intelligible. In this section, I shall say that the all-subjected principle remains the most plausible normative criterion to assess reforms and drastic changes to democratic representative institutions.

Over the years, political philosophers have constituted the demos in many ways. One may link membership in the demos making the laws with the legal or moral obligation to obey such laws. One may argue that the demos is a set of mutually recognised members (Nozick 1974: chap. 10). One, following democratic theorists such as Goodin (2007) and Fung (2013), may defend the principle of affected interests. The first two alternatives seem too exclusionary. When we link membership with the moral or legal obligation to obey 
laws, we fail to notice those people who are obliged to obey our laws but who are not entitled to membership in the demos (Goodin 2007: 42). When we adopt the Nozickean perspective, we exclude many individuals who are otherwise included in the demos of contemporary liberal democratic regimes.

The principle of affected interests seems a much more promising alternative. On this view, individuals should exercise influence over those decisions that affect one's important interest (Fung 2013; Goodin 2007). In a world where democratic institutions make decisions affecting the interests of individuals who live in other countries and who have little (if any) influence on such institutions, the principle of affected interests, as Fung writes, demands 'institutional reform efforts that alter the boundaries ... to include who are affected but lack influence' (2013: 254). And so, this principle 'would mean giving virtually everyone everywhere a vote on virtually everything decided anywhere' (Goodin 2007: 68). Nevertheless, when we use the principle of affected interests as a normative criterion to assess democratic innovations in the field of democratic representative institutions, it seems overinclusive. The principle of affected interests would ground the evaluation of democratic innovations (both incremental reforms and drastic changes) on terms that clash with the ways trough which representative relationships are constituted and negotiated in contemporary representative democracies. At both the local and national level, residency is the most obvious channel to democratic participation in existing representative democracies. Moreover, unlike the principle of affected interests, the demos of democratic representative institutions is not organised around a problem-based approach. It is true that certain issues may affect different individuals in different places of the world, but, from this observation, it does not follow that all individuals (residents and non-residents) have the same claim to reform democratic representative institutions and the general institutional context where such issues arise. For this reason, it is plausible to adopt the all-subjected principle as a normative criterion for innovating democratic representative institutions. In this way, all individuals (and only those individuals) living under the authority of a democratic representative institutions should have the right to influence decisions that affect them. From the all-subjected principle, a legitimate democratic innovation of representative institutions is a complex mix of rules and practices that improve the prior application of the normative requirement that all and only those who are under the authority of a democratic representative institution are both authors and subjects of the laws.

On these grounds, in the next sections, I shall argue that, despite the entitlement to sanction democratic representative institutions and the possible democratic gains granted by certain forms of democratic innovation, it is very difficult to sanction representative democratic institutions through a process that is fully democratic. In a democratic context, sanctioning democratic representative institutions in a democratic way implies that the burdens of change should be somehow evenly distributed across all those subjected to it. But citizens may be in disagreement on many issues that correlate with the attempt of reforming existing democratic representative institutions. If disagreement is so pervasive, operating at the same time and multi-level, and change must occur in agreement with the all-subjected principle, the fully democratic exercise of one's entitlement to sanction the system of institutions and practices in which generic norms of democracy are realised is very difficult. More often than not, since all members are entitled to influence the solution of all relevant disagreements, and since it is very difficult to grant this entitlement in all the relevant disagreements at the same time, the process leading to a future democratic gain may be only partially democratic. 


\section{Representative Democracy and Disagreements}

It is common to think that democratic representation occurs in a context of disagreement among parties with different worldviews and moral commitments. Hamilton assumes that 'politics is judgment about which benefits ought to accrue to whom under conditions of conflicting norms, needs, interests, or at the very least a condition of constant moral disagreement' (2017: 6). Nadia Urbinati writes that 'proportional representation also recognizes pluralism in the first instance, whereas majoritarianism first recognizes the majority and then tries to deal with the reality of pluralism' (2000: 771). And Dovi argues that 'it should now be evident that any adequate ethics of democratic representation must address the ways in which representatives should advance public policies under conditions of pluralism' (2007: 9). These views take disagreement as a singular. Rather than conceptualising democratic representation vis-à-vis one all-encompassing moral disagreement, I believe it would be useful to identify different disagreements, which I shall call D1, D2, D3, D4, D5, D6, D7, D8, and D9. ${ }^{6}$ In this way, we can study how disagreements shape the relationships between the represented and their representatives, the relationships among the represented, and the relationships among representatives, the represented, and the institutions and practices in which generic norms of democracy are realised.

Citizens of modern democracies may have different goals. In John Rawls's words, 'The political culture of a democratic society is always marked by a diversity of opposing and irreconcilable religious, philosophical and moral doctrines' (Rawls 2005: 64). This kind of disagreement (D1) may occur across representative-represented relations or within the same representative-represented relation (D2). Here the line between D1 and D2 may be blurry. D1 identifies disagreements among groups of people with different religious, philosophical, and moral doctrines. Seen from the outside, people in the group are taken to have the same religious, philosophical, and moral doctrines. D2 identifies disagreements internal to those groups, which, seen from the outside, seem homogeneous. Then citizens may subject representatives to multiple and conflicting standards of evaluation-and this disagreement (D3) is itself to be understood as a characteristic of democratic institutions and practices (Mansbridge 2003). Those who equate a commitment to democracy with a commitment to pluralism tend to hold that all criteria for identifying good representatives are contingent, varying with the particular opinions, interests, and perspectives of different citizens. D3 and D2 might look like one and the same thing. However, D2 expresses the application of moral criteria in a way that exceeds what the representative actually is doing. Someone could say it describes disagreements about congruence and alignment. D3 identifies disagreements on how to evaluate what the representative is doing.

Increasing attention has been paid to the observation that between represented and representative there might be disagreement (D4), and this creates, as Plotke puts it, 'a permanent need for representatives and those who are representing themselves to negotiate their relationship' (1997: 31; see also Mansbridge [2003, 2011]; Urbinati [2006]). Here the represented and the representatives might agree at the D1 and at the D2 level, but, on specific issues, the representative may think it is better to do A while the represented thinks it is better to do B. Representatives, then, will almost inevitably advance public policies that some citizens will endorse and others condemn (D5). In this case, disagreement is about the priority of a certain end over another. At the same time, representatives may disagree with one another on what public policies will contribute to the public good. In this case, in a context in which representatives and represented agree on a certain end, representatives 
disagree on the best means to achieve the end (D6). Then, citizens may favour different conceptions of democratic norms and values. And some democratic citizens can hold some other values to be more important than democratic values (D7). At the same time, democratic citizens will disagree not just about public policies and the standards to evaluate their representatives. Democratic citizens may also possess opposing standards to evaluate democratic representative institutions (D8). For instance, someone can favour democratic representative institutions because such institutions allow one group of citizens to dominate another group. Others may favour democratic representative institutions because they ensure stability and good governance. Others may favour democratic institutions because they mirror the moral diversity of modern democracies.

In representative democracy, citizens may envision better-than-existing democratic representative institutions in different ways (D9). Typically, someone may argue that a circle of experts may represent the interests of all citizens better-than-existing democratic representative institutions. Someone else may favour mini-publics or citizen panels. Elites may be for parliamentary reforms. And disadvantaged groups may envision deliberative democratic institutions and practices that, in their own architecture, consider the frequent experience of marginalisation.

Therefore, as Table 1 shows, what we tend to consider as the disagreement comprises (at least) nine kinds of disagreement that inform the process of democratic representation and the resulting relationships between representatives and the citizens they claim to represent. In this context, if the degree to which democratic representation is democratic depends upon the degree to which it realises the all-subjected principle, the different disagreements that characterise representative democracies may function as firewalls during the process of sanctioning democratic representative institutions. Like firewalls, many simultaneous fronts of disagreement may inhibit change by recalling that, for each area of disagreement, each member of the demos ought to be both author and subject of the relevant solution. With these words, I am not saying disagreements are bad for democratic representation. Specifically, each disagreement is an alert calling for all subjected by a collectively binding decision, such as one changing the system of institutions and practices (or a part of it), to monitor and control and have a say. Then, as table 1 shows, some of these disagreements, such as D1 and D7,

TABLE 1.

Disagreements in representative democracies

\begin{tabular}{|c|c|c|c|}
\hline & Who & Object & Character \\
\hline D1 & Groups & Conception of the good & Polarising \\
\hline D2 & Members of the group & $\begin{array}{c}\text { Varieties of the same conception of } \\
\text { the good }\end{array}$ & Deliberative \\
\hline D3 & Represented & What representatives have done & $\begin{array}{l}\text { Polarising and } \\
\text { Deliberative }\end{array}$ \\
\hline D4 & $\begin{array}{l}\text { Represented and } \\
\text { Representatives }\end{array}$ & Public issues & Deliberative \\
\hline D5 & Representatives & Ends & Deliberative \\
\hline D6 & Representatives & Means & Deliberative \\
\hline D7 & Members of the demos & Conceptions of democracy & Polarising \\
\hline D8 & Members of the demos & Standards & $\begin{array}{l}\text { Polarising and } \\
\text { Deliberative }\end{array}$ \\
\hline D9 & Members of the demos & $\begin{array}{l}\text { Better-than-existing representative } \\
\text { institutions }\end{array}$ & Deliberative \\
\hline
\end{tabular}


might be deeper and polarising. But many other disagreements, such as D2, D4, D5, D6, and D9, are opportunities for deliberation between representatives, between represented and representatives, or among members of the demos as a whole. D3 and D8 may be either polarising or occasions for mediation and compromise.

So far, I have constructed a conceptual architecture to study democratic representation and sanctions to representative democratic institutions in societies in which people disagree on many things. First, I have provided a definition of democratic representation. Second, I have demonstrated that democratic representation implies two kinds of sanction. Third, I have identified the democratic module of innovations in democratic representative institutions. Fourth, I have argued that democratic representation occurs in a context in which members of the demos disagree in a number of ways. In the next section, I bring together the four steps of my argument.

\section{Sanctioning Democratically}

Represented and representatives are entitled to sanction institutions and practices, but disagreements, which are an inherent feature of modern representative democracies, function as firewalls that may safeguard democratic institutions against the prospect of change. In a context of different interests and needs, members of a democratic political community who feel they are misrepresented exercise their entitlement to sanction democratic institutions and practices in a fully democratic way only when all firewalls are disabled. However, there might be a gap between a demand for political transformation and the requirement that all members of the political community should have an equal opportunity to influence collectively binding decisions and actions. In plural and democratic societies, where members disagree on many things, it is already difficult to find public decisions that all-affected subjects can see as legitimate. Yet, drastic changes and incremental reforms make things even more difficult. Changes and reforms involve a special kind of decision, one that encompasses several disagreements at the same time. In this section, I will defend this claim by using four examples: inclusive minority, nonconformist minority, homogeneous majority, and plural majority.

\section{Inclusive Minority}

In the past two decades, participatory and deliberative democrats (e.g., Fishkin 2009; Fung 2004) have studied a number of different forms of democratic innovation, such as participatory budgeting (Syntomer et al. 2008), citizen panels, constitutional conventions (White 2017), deliberative polls (Fishkin 2009), and assemblies (Warren and Pearse 2009). And discussions are still underway (e.g., Curato et al. 2017; Lupia and Norton 2017; Shapiro 2017). The literature displays so many examples (e.g., Fung 2004; Warren and Pearse 2009; Zurn 2007) that it is impossible to account for the technicalities of each case in the present paper.

To be institutionalised in a way that significantly reshapes representative democratic institutions, innovations require at least two things: agreement with a certain conception of democracy (Fung 2005), and agreement between a subset of represented and representatives who claim that existing institutional arrangements can be made more representative through democratic experiments. Here the easy way would be to say that members of the demos disagree on both fronts. For instance, Shapiro argues that deliberation may weaken representative democracies (2017). And disputes about the representativeness of deliberative fora are far 
from settled (Brown 2006). Let us, however, try to go a little deeper into the ways democratic societies have implemented forms of democratic innovations. Usually, a subset of representative and represented motivates changes without appealing to a specific conception of the good or to a distinctive representative relationship. They draw upon a conception of democracy that all members of the demos could accept. Therefore, the claim is not eminently partisan. In this way, innovators can disable a number of different firewalls (D1, D2, D3, D4, D5, D7, and D8).

However, members of the demos may envisage different better-than-existing representative democratic institutions (D9), or they may disagree on these experiments as the best means to deliver certain public goods (D6). So, for the move towards democratic representative institutions, which are deliberative in spirit, to be fully democratic, members of the inclusive minority should find ways to convince other members of the demos (e.g., Fung 2005). Notably, if we hold that the inclusive minority can disable D7, the two open firewalls do not make democratic innovations undesirable. They are possible and, perhaps, for the betterment of the whole demos. Nevertheless, D9 and D6 show that, even if the goal is laudable and concerns with democratic representative institutions are widely shared, changes themselves may occur in ways that partially fulfil the all-subjected principle.

\section{Nonconformist Minority}

When democratic institutions and practices exclude a minority group of representatives and represented from institutionalised channels of decision-making, both poles of the relationship of representation may be active, but their interests and needs remain at the periphery of institutionalised law making for reasons that go beyond what the representatives and the represented aim to convey or what the representatives do and how the represented judge these actions.

For instance, in the United States, there are several obstacles faced by new and small parties. For example, in countries such as Canada, the UK, and the United States, proportional representation is central to the agenda of several Green Parties. Recently, in the UK, leaders of parties such as the Green Party and the UK Independence Party have complained that winnertake-all systems cause systematic under-representation of certain interests and groups, despite favourable electoral results.

In these examples, a subset of represented and representatives claim that institutional arrangements deny them meaningful spaces to influence institutions-led actions, but this claim remains eminently partisan. In other words, other members of the political community, whose respective representative relationships revolve around different claims, do not necessarily share these concerns or the interest in reforming existing democratic institutions. For example, in the UK, on 5 May 2011, a nationwide vote took place on whether to change the system for electing the House of Commons, but the proposal to introduce a system of preferential voting was rejected by the electorate.

Moreover, the example of the Green Party suggests representatives and represented envisage analogous ways to reform democratic institutions. But this is not always the case. To the contrary, within party lines, some representatives and represented may contemplate strategic moderation and favour coalition strategies. Others may opt for extending social and political networks outside institutions. So the case of the nonconformist minority disables only two firewalls that safeguard democratic institutions and practices: disagreement among represented people who are represented by the same representatives (D2), and, perhaps, 
disagreement between such representatives and the holders of the interests they claim to represent (D4).

In an unfavourable political and institutional democratic landscape, the represented and their representatives, both of whose intent is not to doubt the democratic character of their society and the democratic character of representation, can exercise the entitlement to sanction democratic institutions and practices in ways that do not question other relationships of representation. Boycotts and strikes are notable examples of sanctions against democratic institutions and practices that do not directly affect the specific character of other relationships of representation. They may induce considerations regarding democratic institutions and practices by contesting the authority of specific collectively binding decisions that affect the interests of otherwise-neglected representatives and represented. Notably, these actions do not address the architecture of democratic institutions, but, in the long run, they may be strategic for bringing into being an environment that supports innovation in democratic systems.

For nonconformist minorities, the entitlement to sanction democratic institutions and practices can help strengthen democratic capacities and practices. These democratic discourses may place the legitimacy of certain decisions at issue while insisting that democratic politics has to be a politics of and about representation. In the same vein, for all disadvantaged categories for which democratic representation has meant exclusion, prevarication, and reification, a non-institutional oppositional sphere may favour decentralising the political discussion.

In this way, nonconformist minorities may cast light upon exclusionary configurations of democratic institutions and practices and, by deconstructing the construction of imaginary interests and needs that dominant representatives claim to represent, inspire otherwise represented citizens to embrace their cause up to the point that the subsequent coalition can disable all firewalls that block institutional innovation.

\section{Homogeneous Majority}

The story changes when a relatively homogeneous majority group of representative and represented aims to change democratic institutions and practices. The case of the despotic majority shows that democratic representative institutions are vulnerable to ways of reforming democratic institutions and practices that undermine their democratic character from within. Representatives may come up with a number of different reasons to change the same representative system that has already put them in a position of power. Emergency, stability, and governability of democracy are three prominent justificatory strategies to argue for reforms of the representative system without (explicitly) challenging its democratic credentials.

For instance, on 16 April 2017, sponsored by the governing Justice and Development Party and the Nationalist Movement Party, a constitutional referendum was held in Turkey to reform the existing parliamentary system, curb the power of the parliament, and grant sweeping powers to the president, Recep Tayyip Erdogan. All this came together with the closure of hundreds of non-elected representative groups, allegedly 'working against the state'.

The despotic majority does not disable any firewalls that safeguard democratic institutions and practices other than disagreement among represented who have the same representatives (D2), and disagreement between represented and representatives (D4). However, a despotic majority outnumbers the rest of the political community. And this opens space to measures that may sanction the democratic institutions and practices by using nondemocratic or quasi-democratic instruments. 
These measures may be different in character and in their targets. Erdogan banned NGOs and civil-society organisations. In India, the license of several NGOs was revoked for 'antinational activities'. Moreover, democratic institutions and practices may be sanctioned through referenda, public consultation, and plebiscites that fundamentally reform the architecture of the representative system and establish a single-party system. Elections and other formal trappings of representative democracy persist but lose meaning, since authority is centralised and representatives are not accountable for the decisions of strongmen.

A despotic majority may weaken democratic practices and capacities. It ascribes aims, interests, and needs to the represented, but these aims, interests, and needs are not subject to dialogue and instead serve the legitimising discourse of the executive power and its fellows in weak representative institutions.

An analogous discourse is valid when we consider the case of a benevolent majority. A benevolent majority is homogeneous and aims to change democratic institutions and practices in order to include otherwise-neglected interests. By doing so, the benevolent majority ascribes a list of interests and needs to other members of the political community. It acts as if democratic firewalls have been disabled, when, in fact, they have not.

\section{Plural Majority}

Despotic majority is not the only kind of majority that can aim to change democratic institutions and practices. A majority composed of a series of elected and non-elected claimants with different interests and needs may aim for reforms of democratic institutions and practices when these institutions are exclusionary or have limited decision-making power.

A variegated majority of European stakeholders has drawn attention to the democratic deficit of EU institutions. Over the past 30 years, EU treaties have regularly increased the powers of the European Parliament. Nevertheless, media, politicians, social movements, civil-society groups, scholars, and citizens still claim that a democratic deficit affects the EU. National parliaments have cast doubts on the European Parliament's democratic credentials. Notably though, several national politicians and civil-society groups are ignorant about the EU and its rules. Moreover, representatives and members of civil-society groups have complained that EU procedures and a technical policy language are informal obstacles that leave some interests at the margins of institutionalised democratic institutions and practices.

Supporters of reforms may disagree on the design of the new representative institutions (D9). Actually, there have been hundreds of proposals to reform representative institutions in the EU. Further, members of the coalition of reformers may continue defending their interests and needs, and the reasons for reforming EU institutions may be different from one claimant to another (D1).

Therefore, even in this case, despite a common interest in reforming democratic institutions and practices, in plural societies, the tenacity of other firewalls may affect the process of changing democratic representative institutions in fully democratic ways. In a context in which members of the demos disagree on many things, and changes involve special kinds of decision that encompass several fronts of disagreement at the same time, the cases of the inclusive minority, nonconformist minority, despotic and benevolent majorities, and plural majority show that it is very difficult for the process of sanctioning democratic representative to unfold in a way that is fully compliant with the all-subjected principle. If representatives and those they represent feel they are misrepresented, they are entitled to sanction democratic institutions and practices. The fully democratic exercise of this 
entitlement is another story. Unless citizens across the spectrum of all representative relationships feel they are misrepresented (and agree on the prospect of change), sanctions may cause violations of the democratic principle that all members of the demos are not mere objects of legislation or external coercion.

\section{Conclusion}

My argument has provided a, perhaps pessimistic, account of democratic change in democratic representative institutions. The perspective may seem pessimistic because it says it is very difficult to change democratic representative institutions while remaining compliant with the all-subjected principle in all areas of disagreement. Representatives and represented can have noble democratic intentions and produce good democratic innovations. But, even from a conceptual standpoint, the process leading to these changes may entail some violations of the fundamental all-subjected principle.

In this context, I have argued that citizens have an entitlement to sanction representatives, but representatives have tools to anticipate this sanction and reconstruct their views in order to anticipate the views of the people they are supposed to represent. I also have argued that represented and representatives have an entitlement to sanction democratic institutions and practices, but a number of different disagreements may complicate the process of reforming institutions and practices in fully democratic ways. Overall, this paper clarifies the normative justification of sanctions in the context of plural representative democracies. At the same time, it opens a research line on disagreement within and about representative democracies. Disagreements are many and with different consequences. Here I have focused my attention on one of those implications: how disagreements may affect the democratic character of processes leading to change democratic representative institutions.

\section{ACKNOWLEDGEMENTS}

For insightful comments, I wish to thank three anonymous reviewers for this journal, Stephen Elstub, and the rest of the Representation editorial team. Earlier drafts received excellent feedback at the 2017 ASPP Conference at the University of Sheffield and at the 2017 ECPR General Conference in Oslo.

\section{DISCLOSURE STATEMENT}

No potential conflict of interest was reported by the author.

\section{NOTES}

1. For this reason, all members of the demos are de facto subjected to all laws, changes and legislation within the jurisdiction of the state.

2. This does not mean to say that represented are misrepresented. Like Severs (2010), I agree that there is a significant conceptual difference between being misrepresented and feeling misrepresented. However, in this case, this conceptual difference is particularly thin. Represented citizens establish new representative relationships. And there might be a number of different reasons for these new representative relationships, and many of these reasons might not be fully rational. For instance, manipulatory politics may convince represented citizens that their 
representatives are misrepresenting them, represented citizens may have new interests and needs because of a particularly short-sighted view, and moral sentiments such as friendship, anger, and love may affect political preferences of represented citizens.

3. Dovi puts this in the context of an ethics of democratic representation. In her view, an ethics of democratic representation should help democratic citizens to be in a better position to 'differentiate between the faults of representative institutions (e.g. improper norms or procedures for determining policies) and bad performance of individual representatives' (Dovi 2007: 49).

4. For a programme of reform that allows for resistance and a series of institutional means to overcome structures of domination, see Hamilton (2014).

5. When all citizens accept the justification for sanctioning democratic practices and institutions, it seems plausible to think that they not only feel that they are misrepresented, but they are misrepresented, regardless of what democratic institutions do.

6. I have derived the list of disagreement deductively from theoretical expectations about a standard situation of institutional change in plural liberal democracies. My list aims at offering the essential fronts of disagreements. It is by no means exhaustive. There might be many other sources of disagreement, but they would not change the nature of my argument. Actually, the more disagreements we have, the more difficult it becomes to change democratic representative institutions in ways that accommodate the all-subjected principle fully.

\section{ORCID}

Corrado Fumagalli (D) http://orcid.org/0000-0002-5402-162X

\section{REFERENCES}

BENHABIB, SEYLA. 2004. The Rights of Others: Aliens, Residents and Citizens. Cambridge: Cambridge University Press.

BROWN, MARK B. 2006. Survey article: citizen panels and the concept of representation. Journal of Political Philosophy 14: 203-25.

CASTIGLIONE, DARIO and MARK E. WARREN. 2013. A new ecology of democratic representation? Eight theoretical issues. Rivista di Storia delle Idee 2: 155-72.

CHRISTIANO, THOMAS. 2008. The Constitution of Equality: Democratic Authority and Its Limits. Oxford: Oxford University Press.

CURATO, NICOLE, DRYZEK JOHN S., ERCAN SELEN A., HENDRIKS CAROLYN M. and NIEMEYER SIMON. 2017. Twelve key findings in deliberative democracy research. Daedalus 146: 28-38.

DISCH, LISA. 2011. Toward a mobilization conception of democratic representation. American Political Science Review 105: 100-14.

DOVI, SUZANNE. 2002. Preferable descriptive representatives: Will just any woman, black, or latino do? American Political Science Review 96: 729-43.

Dovi, SUZANNE. 2007. The Good Representative. Oxford: Blackwell.

FISHKIN, JEREMY. 2009. When the People Speak. Oxford: Oxford University Press.

FUNG, ARCHON. 2004. Empowered Participation: Reinventing Urban Democracy. Princeton, NJ: Princeton University Press.

FUNG, ARCHON. 2005. Deliberation before the revolution: towards an ethics of deliberative democracy in an unjust world. Political Theory 33: 397-419. 
FUNG, ARCHON. 2013. The principle of affected interests: an interpretation and defense. In Representation: Elections and Beyond, edited by Jack Nagel and Rogers Smith. Philadelphia: University of Pennsylvania Press, pp. 236-68.

GARGARELLA, ROBERTO. 2003. The last resort: the right to resistance in situations of legal alienation. SELA Papers, Paper 23. Available at http://digitalcommons.law.yale.edu/yls_sela/23.

GIGER, NATHALIE and ZOE, LEFKORIDI. 2016. Alignment of objectives between parties and their electors: the role of personal issue salience in political representation. In Political Representation: Roles, representatives and the represented, edited by Marc Buhlmann and Jan Fivaz. London and New York: Routledge, pp. 135-51.

GINSBURG T., DANIEL LANSBERG-RODRIGUEZ and MILA VERSTEEG. 2013. When to overthrow your government: the right to resist in the world's constitutions. UCLA Law Review 60: 1186-260.

GOODIN, ROBERT. 1980. Manipulatory Politics. New Haven, CT: Yale University Press.

GOODIN, ROBERT. 2007. Enfranchising all affected interests, and its alternatives. Philosophy and Public Affairs 35: 40-68.

GOULD, CAROL. 2006. Self-determination beyond sovereignty: relating transnational democracy to local autonomy. Journal of Social Philosophy 37: 44-60.

GUTMANN, AMY and DENNIS THOMPSON. 2004. Why Deliberative Democracy? Princeton, NJ: Princeton University Press.

habermas, JuRgen. 1996. Between Facts and Norms. Trans. W. Regh. Cambridge MA: Polity Press. hamilton, LAWRenCe. 2014. Freedom Is Power: Liberty Through Political Representation. Cambridge: Cambridge University Press.

HAMILTON, LAWRENCE. 2017. Representation Needs Resistance. Representation 53: 81-95.

KAUfMANN A. 1985-86. Small scale right to resist. New England Law Review 21: 571-80.

KUYPER, JONATHAN W. 2016. Systemic representation: democracy, deliberation, and nonelectoral representatives. American Political Science Review 110: 308-24.

LefeVere, Jonas, StefaAn, Walgrave, and michiel, nuytemans. 2017. Studying the voter-party match: congruence and incongruence between voters and parties. In Political Representation: Roles, Representatives and the Represented, edited by Marc Buhlmann and Jan Fivaz. London and New York: Routledge, pp. 152-69.

LUPIA, ARTHUR and ANNE NORTON. 2017. Inequality is always in the room: language and power in deliberative democracy. Daedalus 146: 64-76.

MANIN, BERNARD. 1997. The Principles of Representative Government. Cambridge: Cambridge University Press.

MANION, MELANIE. 2015. Information for Autocrats: Representation in Chinese Local Congresses. Cambridge: Cambridge University Press.

MANSBRIDGE, JANE. 1999. Should blacks represent blacks and women represent women? A contingent "yes." Journal of Politics 61: 628-57.

MANSBRIDGE, JANE. 2003. Rethinking representation. American Political Science Review 97: 515-28.

MANSBRIDGE, JANE. 2009. A 'selection model' of political representation. Journal of Political Philosophy 17: 369-98.

MANSBRIDGE, JANE. 2011. Clarifying the concept of representation. American Political Science Review 105: 621-30.

MONTANARO, LAURA. 2012. The democratic legitimacy of self-appointed representatives. Journal of Politics 74: 1094-107.

NÄSSTRÖM, SOFIA. 2007. The legitimacy of the people. Political Theory 35: 624-58.

NÄSSTRÖM, SOFIA. 2011. The challenge of the all-affected principle. Political Studies 59: 116-34.

NÄSSTRÖM, SOFIA. 2015. Democratic representation beyond election. Constellations 22: 1-12. 
NOZICK, ROBERT. 1974. Anarchy, State, and Utopia. New York: Basic Books.

PENSKY, MAX. 2007. Two cheers for cosmopolitanism: cosmopolitan solidarity as second-order inclusion. Journal of Social Philosophy 38: 165-84.

PITKIN, HANNA. 1967. The Concept of Representation. Berkeley: University of California Press.

PLOTKE, DAVID. 1997. Representation is democracy. Constellations 4:19-34.

RAWLS, JOHN. 2005. Political Liberalism: Extended Version. New York: Columbia University Press.

REHFELD, ANDREW. 2006. Towards a general theory of political representation. Journal of Politics 68:

$1-21$.

REHFELD, ANDREW. 2009. Representation rethought: on trustees, delegates, and gyroscopes in the study

of political representation and democracy. American Political Science Review 103: 214-30.

REHFELD, ANDREW. 2011. The concepts of representation. American Political Science Review 105: 631-41. REHFELD, ANDREW. 2018. On representing. Journal of Political Philosophy 26: 216-39.

RUNCIMAN, DAVID. 2007. The paradox of political representation. Journal of Political Philosophy 15: 93-114.

SAWARD, MICHAEL. 2009. Authorisation and authenticity: representation and the unelected. Journal of Political Philosophy 17: 1-22.

SAWARD, Michael. 2010. The Representative Claim. Oxford: Oxford University Press.

SEVERS, ELINE. 2010. Representation as claims-making. Quid responsiveness? Representation 46: 411-23. SHAPIRO, IAN. 2017. Collusion in restraint of democracy: against political deliberation. Daedalus 146: 77-84.

SKIRBEKK, GUNNAR. 1997. The discourse principle and those affected. Inquiry 40: 63-71.

SQUIRES, JUDITH. 2008. The constitutive representation of gender: extra-parliamentary re-presentation of gender relations. Representation 44: 187-204.

SYNTOMER, YVES, C. HERZBERG and A. RÖCKE. 2008. Participatory budgeting in Europe: potentials and challenges. International Journal of Urban and Regional Research 32: 164-78.

syntomer, yVes. 2010. The Power to the People. Citizen juries, Random Selection and Participative Democracy. Exeter: Imprint Academic.

URBINATI, NADIA. 2000. Representation as advocacy: a study of democratic deliberation. Political Theory 28:758-86.

URBINATI, NADIA. 2006. Representative Democracy: Principles and Genealogy. Chicago, IL: University of Chicago Press.

URBINATI, NADIA and MARK E. WARREN. 2008. The concept of representation in contemporary democratic theory. Annual Review of Political Science 11: 387-412.

WARREN, MARK E. and HILARY PEARSE. 2009. Designing deliberative democracy: the British Columbia citizens' assembly. Cambridge: Cambridge University Press.

WHITE, STUART. 2017. Parliaments, constitutional conventions, and popular sovereignty. British Journal of Politics and International Relations. doi: 10.1177/1369148117700657. Online March 30, 2017. WOLIN, SHELDON. 1982. What revolutionary action means today. Democracy 4: 17-28. YOUNG, IRIS MARION. 2000. Inclusion and Democracy. Oxford: Oxford University Press. ZURN, CHRISTOPHER. 2007. Deliberative Democracy and the Institutions of Judicial Review. Cambridge: Cambridge University Press. 